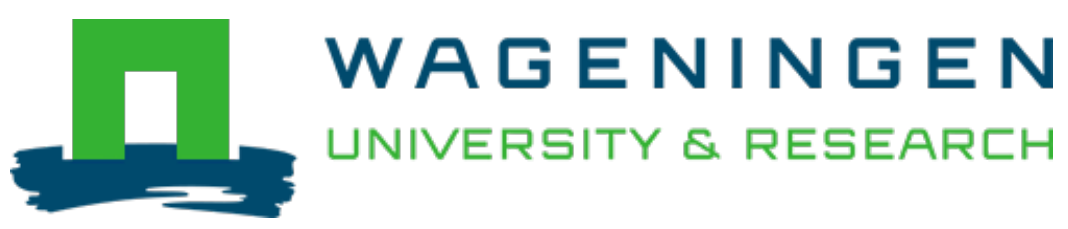

\title{
Application of bio-desalinization for reclamation of salt-affected soil under composted cow manure and deficit irrigation with saline water
}

\author{
Paddy and Water Environment \\ Kalanaki, Mahdi; Ritzema, Henk; Bamshad, Roghayeh; Jones, Edward; Fazilatnia, Mojtaba \\ https://doi.org/10.1007/s10333-020-00795-7
}

This article is made publicly available in the institutional repository of Wageningen University and Research, under the terms of article $25 \mathrm{fa}$ of the Dutch Copyright Act, also known as the Amendment Taverne. This has been done with explicit consent by the author.

Article 25 fa states that the author of a short scientific work funded either wholly or partially by Dutch public funds is entitled to make that work publicly available for no consideration following a reasonable period of time after the work was first published, provided that clear reference is made to the source of the first publication of the work.

This publication is distributed under The Association of Universities in the Netherlands (VSNU) 'Article $25 \mathrm{fa}$ implementation' project. In this project research outputs of researchers employed by Dutch Universities that comply with the legal requirements of Article $25 \mathrm{fa}$ of the Dutch Copyright Act are distributed online and free of cost or other barriers in institutional repositories. Research outputs are distributed six months after their first online publication in the original published version and with proper attribution to the source of the original publication.

You are permitted to download and use the publication for personal purposes. All rights remain with the author(s) and / or copyright owner(s) of this work. Any use of the publication or parts of it other than authorised under article $25 \mathrm{fa}$ of the Dutch Copyright act is prohibited. Wageningen University \& Research and the author(s) of this publication shall not be held responsible or liable for any damages resulting from your (re)use of this publication.

For questions regarding the public availability of this article please contact openscience.library@,wur.nl 


\title{
Application of bio-desalinization for reclamation of salt-affected soil under composted cow manure and deficit irrigation with saline water
}

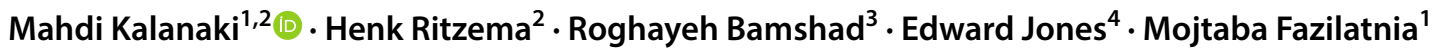

Received: 31 July 2019 / Revised: 30 January 2020 / Accepted: 12 February 2020

(c) The International Society of Paddy and Water Environment Engineering 2020

\begin{abstract}
Application of common leaching and flushing methods is often impractical due to freshwater scarcity, groundwater pollution and a lack of suitable drainage systems. To address these problems, a pot experiment testing the cultivation of Salicornia persica Akhani was conducted in three replicates. Three saline irrigation treatments $\left(E C=7.2 \mathrm{dS} \mathrm{m}^{-1}\right)$ were used: full irrigation with saline water (SI), deficit irrigation with 75\% of SI (DSI 75 ) and deficit irrigation with 55\% of SI (DSI ${ }_{55}$ ). Two soil conditions also were considered, namely a combination of soil with $10 \%$ composted cow manure (CM) and soil without manure (WA). Our results show that the highest values for stem diameter $(3.1 \mathrm{~mm})$, height $(110.1 \mathrm{~mm})$ and dry weight $(0.5 \mathrm{~g})$ were observed in SI-CM. Conversely, the highest values for root length with $16.9 \mathrm{~mm}$ and root weight with $0.7 \mathrm{~g}$ were obtained for $\mathrm{DSI}_{75}-\mathrm{CM}$. The best treatment for water-use efficiency (WUE) was DSI $75^{-\mathrm{CM}}$ with $2.6 \mathrm{~g}^{-1}$, and the lowest WUE of $1.33 \mathrm{~g} \mathrm{l}^{-1}$ was observed for $\mathrm{DSI}_{55}$-WA. DSI increased all examined chemical parameters. The use of CM only resulted in increased values of carbohydrate, protein and proline, with no significant effects found for other parameters. Significant reductions in both EC $(38.6 \%)$ and $\mathrm{Na}^{+}(16.8 \%)$ occurred in both soil treatments, with reductions under WA higher than reductions under CM. Overall, our results suggest that the proposed methods could be used for decreasing soil salinity levels while simultaneously allowing for the use of saline water for agricultural production.
\end{abstract}

Keywords Halophytes $\cdot$ Soil amendments $\cdot$ Soil salinity $\cdot$ Salicornia persica

\section{Introduction}

Expected population growth to 9.1 billion people by 2050 will intensify food security issues around the globe (Béné et al. 2015). Soil salinization and freshwater scarcity exacerbate this challenge, especially in arid and semiarid regions (Min et al. 2014; Talebnejad and Sepaskhah 2015). Aridity, drought, desertification and water shortages are some of the different causes of water scarcity (Pereira et al. 2002). Salinization is a type of soil degradation that occurs

Mahdi Kalanaki

Kalanaki_mahdi@yahoo.com; m_kalanaki@alumni.ut.ac.ir

1 Water Engineering Department, University of Zabol, Zabol, Iran

2 Water Resource Management Group, Wageningen University and Research, Wageningen, The Netherlands

3 Department of Horticulture, Faculty of Agriculture, University of Zabol, Zabol, Iran

4 Water Systems and Global Change Group, Wageningen University and Research, Wageningen, The Netherlands when salts accumulate at the soil surface (Sardinha et al. 2003). Salt-affected soils can be divided into three different branches: saline, sodic and alkaline soils. The development of irrigation in arid environments is a major reason for the increasing salinity problems, potentially leading to fossil salt mobilization and secondary salinization (Smedema and Shiati 2002). The leaching fraction is designed to avoid the accumulation of salt at the soil surface under irrigation. However, this method has two major disadvantages: (1) consumption of (often scarce) freshwater resources and (2) pollution of groundwater and water table increases. Although suitable drainage systems can decrease the disadvantages of leaching techniques, both social opposition to and financial constraints for developing drainage systems can limit the viability of this option. In addition to salinity problems associated with agricultural activities, industrial and municipal processes produce large volumes of saline water (Ayars et al. 2006; Miyamoto and Chacon 2006). Total dissolved salts in these waters can range from 1000 to above $7000 \mathrm{mg} \mathrm{l}^{-1}$, which may be dangerous for the soil, groundwater and environment (Glenn et al. 2009). 
To combat both freshwater scarcity and food security issues, many researchers have suggested the potential for sustainable cultivation of edible halophytes (Böer et al. 2016; Cheeseman 2015; Kalantari et al. 2018; Qureshi 2017; Teh and Koh 2016). Halophytes are salt-tolerant plants that can be separated in two different families including obligate and facultative halophytes. The cultivation of obligate halophytes requires a level of salinity for their optimum growth, while facultative halophytes can complete their life cycle under both saline and non-saline conditions (Flowers and Colmer 2008; Nikalje et al. 2018). The phyto-desalination properties of some halophytes, which can absorb high levels of salt in their biomass, may also improve soil quality, a key aspect of sustainable development. As such, phyto-desalination has been an attractive subject for researchers in previous years (Manousaki et al. 2014; Nouri et al. 2017; Rabhi et al. 2009; Reddy et al. 2010; Sakai et al. 2012).

One member of the halophytes group is Salicornia, which is categorized as a $\mathrm{C} 3$ annual species plant (Ayala and O'Leary 1995) and as an obligate halophyte. The suitable water salinity range for optimum growth of Salicornia is from 11 to $20 \mathrm{dS} \mathrm{m}^{-1}$ (Ohori and Fujiyama 2011). Osmoregulators in halophytes, especially Salicornia, have interesting properties such as sugars and free proline, which prohibits loss of water and ion toxicity of cells (Akcin and Yalcin 2016; Ashraf and Foolad 2007; Bohnert et al. 1995). Furthermore, this plant is suitable for human consumption (Price 2007). Other potentially useful applications of Salicornia include livestock feed (Glenn et al. 1998), bioenergy (Akinshina et al. 2016; Falasca et al. 2014), medication (Gunning 2016) and as a nutritive and healthy oil (Liu et al. 2005). Moreover, Salicornia can absorb salt from soil and decrease soil salinity and toxicity of ions (Atzori et al. 2019).

Saline irrigation management is a very important factor for desalinization under bio-drainage technique because full irrigation with saline water or drainage water may pollute groundwater (Caraballo et al. 2016; Ostad-Ali-Askari et al. 2017). In these conditions, the application of less-waterintense irrigation strategies, such as deficit irrigation (DI), may play a useful role. DI is an irrigation management for saving water (Al-Ghobari and Dewidar 2018; Galindo et al. 2018) and aims to maximize water productivity rather than maximizing yields (Brar et al. 2018; Jonubi et al. 2018). Additionally, DI may increase the quality of yield and grain size (Dorji et al. 2005; Nakawuka et al. 2017), reduce fungal diseases risks (Guilpart et al. 2017), reduce nutrient leaching through root zone, improve groundwater quality and decrease the need for additional fertilizer applications (Brar et al. 2018; Carlton et al. 2016; Jonubi et al. 2018). In these ways, deficit irrigation with saline water could present a solution for decreasing environments risks by reducing drainage water, while also promoting food and freshwater security (Aly et al. 2018; de Melo et al. 2018; Muschal
2006). However, a reduction in the volume of water used for deficit irrigation also limits the amount of leaching that can occur, thus potentially promoting salt accumulation in the soil (Glenn et al. 2009). The phyto-desalination properties of halophytes could play an essential role for desalinization. As a result, bio-saline agriculture could achieve win-win effects through the improvement in both soil quality and crop production.

Another solution for decreasing the negative effects of saline water irrigation is represented by soil amendments. Composted cow manure is a readily available soil amendment in most areas of the world (Devi et al. 2018; Pamarthy et al. 2016). Increased availability of nutrients in the environment may enhance crop production (Pandey and Patra 2015; Zandvakili et al. 2017), increasing the level of soil organic matter (Bistgani et al. 2018) and reducing environmental footprints (Afshar et al. 2014; Nazli et al. 2016). These features are very advantageous, especially in poor soils in arid and semiarid regions. In this regard, little or no information was found on the optimum levels of deficit irrigation for achieving the best results in biomass production and soil desalination in a short time, especially when simultaneously combined with soil amendments. Hence, in this study, the effect of three different levels of saline irrigation in soil conditions both including and excluding composted cow manure on a native Salicornia species (i.e., Salicornia persica Akhani) was investigated to address the following objectives:

1. To investigate the response of Salicornia persica Akhani to changes in soil conditions and deficit irrigation treatments with saline water.

2. To determine the best treatment combination for maximizing WUE.

3. To evaluate changes in soil salinity and $\mathrm{Na}^{+}$accumulation after the experiment.

\section{Materials and methods}

\section{Experimental setup}

This research was conducted as a pot experiment with three replicates in a greenhouse at Sistan Agricultural and Natural Resources Research and Education Center located in the south-east of Iran in 2018. The average temperature for day and night was around $33{ }^{\circ} \mathrm{C}$ and $14{ }^{\circ} \mathrm{C}$, respectively. Additionally, the relative humidity and natural photoperiod during the experiment were around $57 \%$ and $10 \mathrm{~h}$, respectively. The soil texture was clay loam, which was gathered from a working farm in Sistan. The air-dried soil passed through a 2-mm sieve. The physicochemical properties of the soil are displayed in Table 1. 
Table 1 Experimental soil texture

\begin{tabular}{llllllllll}
\hline Clay (\%) & Silt (\%) & Sand (\%) & Soil texture & $\mathrm{EC}\left(\mathrm{dS} \mathrm{m}^{-1}\right)$ & $\mathrm{pH}$ & $\begin{array}{l}\mathrm{Na}^{+} \\
\left(\mathrm{meq} \mathrm{1}^{-1}\right)\end{array}$ & $\mathrm{Ca}^{2+}$ & $\mathrm{Mg}^{2+}$ & SAR \\
\hline 37 & 23 & 40 & Clay loam & 8.3 & 8.4 & 62.3 & 356 & 1310 & 2.2 \\
\hline
\end{tabular}

Plastic pots, which were $15 \mathrm{~cm}$ in height and $19 \mathrm{~cm}$ in diameter, were filled with $1600 \mathrm{~g}$ of soil or soil with $10 \% \mathrm{com}$ posted cow manure (CM) according to treatments, without additional chemical fertilizer. Forty-five seeds of Salicornia persica Akhani were planted at March 7, 2018. Each pot was irrigated to field capacity with saline water (Table 2).

The seeds emergence was on March 18, 2018. After that, in two and four weeks after sowing, the plants were thinned. The study was a completely randomized design in a factorial arrangement. All irrigation treatments were done with water of the same salinity level $\left(\mathrm{EC}=7.2 \mathrm{dS} \mathrm{m}^{-1}\right)$, namely SI (full irrigation with saline water), $\mathrm{DSI}_{75}(25 \%$ decrease compared to SI) and $\mathrm{DSI}_{55}$ (45\% decrease compared to SI). Additionally, soil treatments included the application of composted cow manure (CM) at $10 \%$ of the total mass and without it as a control treatment (WA).

\section{Irrigation requirement}

All pots were irrigated with a 2-4 days interval during the experiment. Irrigation for all pots was done the same as SI-WA (control pot) from March 7 until April 5. Application of deficit irrigation treatments began after the early growing period (i.e., April 7). The irrigation volume for control pots was measured before each irrigation time based on mass balance equation by weighing the pots (Eq. 1).

$\mathrm{ETc}=\mathrm{IR}-\mathrm{Dp}+P+\mathrm{Cp}-\mathrm{Ro} \pm \Delta W$.

The components of the equation above are evapotranspiration [ETc $(\mathrm{mm})]$, total irrigation [IR $(\mathrm{mm})]$, deep percolation of root zone $[\mathrm{Dp}(\mathrm{mm})]$, precipitation $[P(\mathrm{~mm})]$, capillary rise $[\mathrm{Cp}(\mathrm{mm})]$, runoff $[\mathrm{Ro}(\mathrm{mm})]$ and changing in soil water content $[\Delta W(\mathrm{~mm})]$, respectively (Allen et al. 1998). Equation (1) can be simplified for a pot experiment to give Eq. 2 .

$\operatorname{ETc}_{(i, i-1)}=\mathrm{IR}_{i-1}-\mathrm{Dp}_{i-1}$.
In (Eq. 2), "ETc" is the evapotranspiration ( $\mathrm{mm})$ between two irrigation intervals $(i, i-1)$, "IR" means irrigation depth $(\mathrm{mm})$ at the past irrigation interval $(i-1)$ and "Dp" is the drainage water volume $(\mathrm{mm})$ for the previous irrigation interval $(i-1)$ that discharged from the drainage holes of pots. To measure drainage volume, three plastic buckets collecting water were set under control pots (i.e., SI-WA). Therefore, drainage water can be saved in them while minimizing evaporation. During the experiment, irrigation and drainage water were controlled by weighing the pots as per Wang et al. (2017).

The WUE $\left(\mathrm{kg} \mathrm{l}^{-1}\right)$ was defined as the ratio between dry weight (DW) $\left(\mathrm{g}_{\text {plant }}{ }^{-1}\right)$ and the amount of water applied to the pot (1 plant $\left.{ }^{-1}\right)$ (Behera and Panda 2009).

$\mathrm{WUE}=\frac{\mathrm{DW}}{\mathrm{IR}}$.

\section{Measurements and lab activities}

At the end of the experiment on 10 May, plant height $(\mathrm{mm})$, stem diameter $(\mathrm{mm})$, root dry weight $(\mathrm{g})$, root length $(\mathrm{mm})$ and dry biomass $\left(\mathrm{g} \mathrm{plant}^{-1}\right)$ were measured (Azhar et al. 2011; Moussavi-Nik et al. 2011; Wang et al. 2017). In addition, some other plant chemical parameters, including carbohydrates $\left(\mathrm{mg} \mathrm{g}^{-1}\right)$, protein $\left(\mathrm{mg} \mathrm{g}^{-1}\right)$, proline $\left(\mathrm{mg} \mathrm{g}^{-1}\right)$, carotenoid $\left(\mathrm{mg} \mathrm{g}^{-1}\right)$, chlorophylls $a$ and $b\left(\mathrm{mg} \mathrm{g}^{-1}\right)$, were determined in the laboratory based on the methods of Csiszar et al. (2007), Zhang et al. (2009), Sikuku et al. (2010) and Saboora et al. (2012).

Soil salinity, $\mathrm{pH}, \mathrm{Na}^{+}$and $\mathrm{K}^{+}$of soil were measured at the beginning and end of the experiment. These values were compared to determine the accumulation and effects of salts on soil under different treatment conditions. Additionally, the accumulation of $\mathrm{Na}^{+}$and $\mathrm{K}^{+}$in the plant was measured based on Ashraf and Orooj (2006) to assess the phyto-desalination characteristics of Salicornia persica under deficit irrigation and composted cow manure.
Table 2 Chemical properties of used saline water

\begin{tabular}{llllllllll}
\hline EC $\left(\mathrm{dS} \mathrm{m}^{-1}\right)$ & $\mathrm{pH}$ & $\mathrm{SAR}$ & $\begin{array}{l}\mathrm{Na}^{+} \\
\left(\mathrm{meq} \mathrm{1}^{-1}\right)\end{array}$ & $\mathrm{Ca}^{2+}$ & $\mathrm{Mg}^{2+}$ & $\mathrm{K}^{+}$ & $\mathrm{HCO}_{3}^{-}$ & $\mathrm{Cl}^{-}$ & $\mathrm{SO}_{4}^{2-}$ \\
\hline 7.2 & 7.6 & 8.3 & 30.8 & 13.1 & 14.2 & 0.23 & 9.1 & 31.2 & 23.9 \\
\hline
\end{tabular}

$E C$ electrical conductivity, SAR sodium absorption ratio 


\section{Data analysis}

In this study, SAS version 9.0 was used to investigate the significant $(p<0.05$ or $p<0.1)$ or nonsignificant effects of treatments using the Duncan test (Dağdelen et al. 2009).

\section{Results and discussion}

\section{Physiological responses}

Figures 1 and 2 show the effects of irrigation and soil treatments on the physiological traits and biomass of Salicornia. The plant height varied from 38.7 to $110.1 \mathrm{~mm} \mathrm{plant}^{-1}$, stem diameter varied from 2.2 to $3.13 \mathrm{~mm}$ plant $^{-1}$, and dry biomass varied from 0.20 to $0.51 \mathrm{~g} \mathrm{plant}^{-1}$, with the highest values observed in SI-CM and lowest ones in $\mathrm{DSI}_{55}$-WA. There were mostly nonsignificant differences between SI and $\mathrm{DSI}_{75}$ during vegetative growth of $S$. persica, while $\mathrm{DSI}_{55}$ shows significant decreases compared to the SI conditions

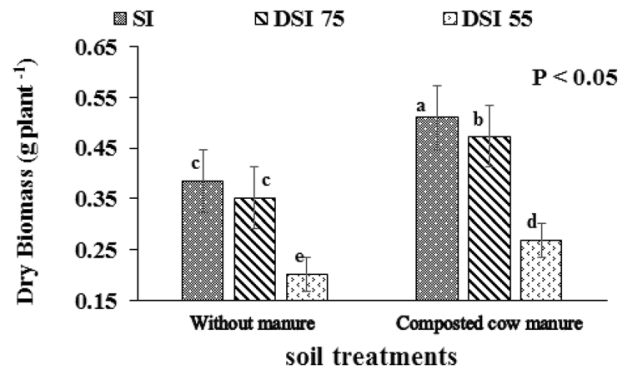

SI: Full irrigation with saline water, DSI75: $75 \%$ of SI and DSI55: $55 \%$ of SI

Fig. 2 Effects of irrigation and soil treatments on dry biomass of $S$. persica. *Values are means \pm s.e. Means with the same letter are not significantly different (Duncan test, level of significance shown in each graph)

in all traits with the exception of root length. Our results are in accordance with the findings of other studies on severe deficit irrigation, with decreases in characteristics such as plant height, stem diameter and biomass compared to control treatments (Bekmirzaev et al. 2019). On the other
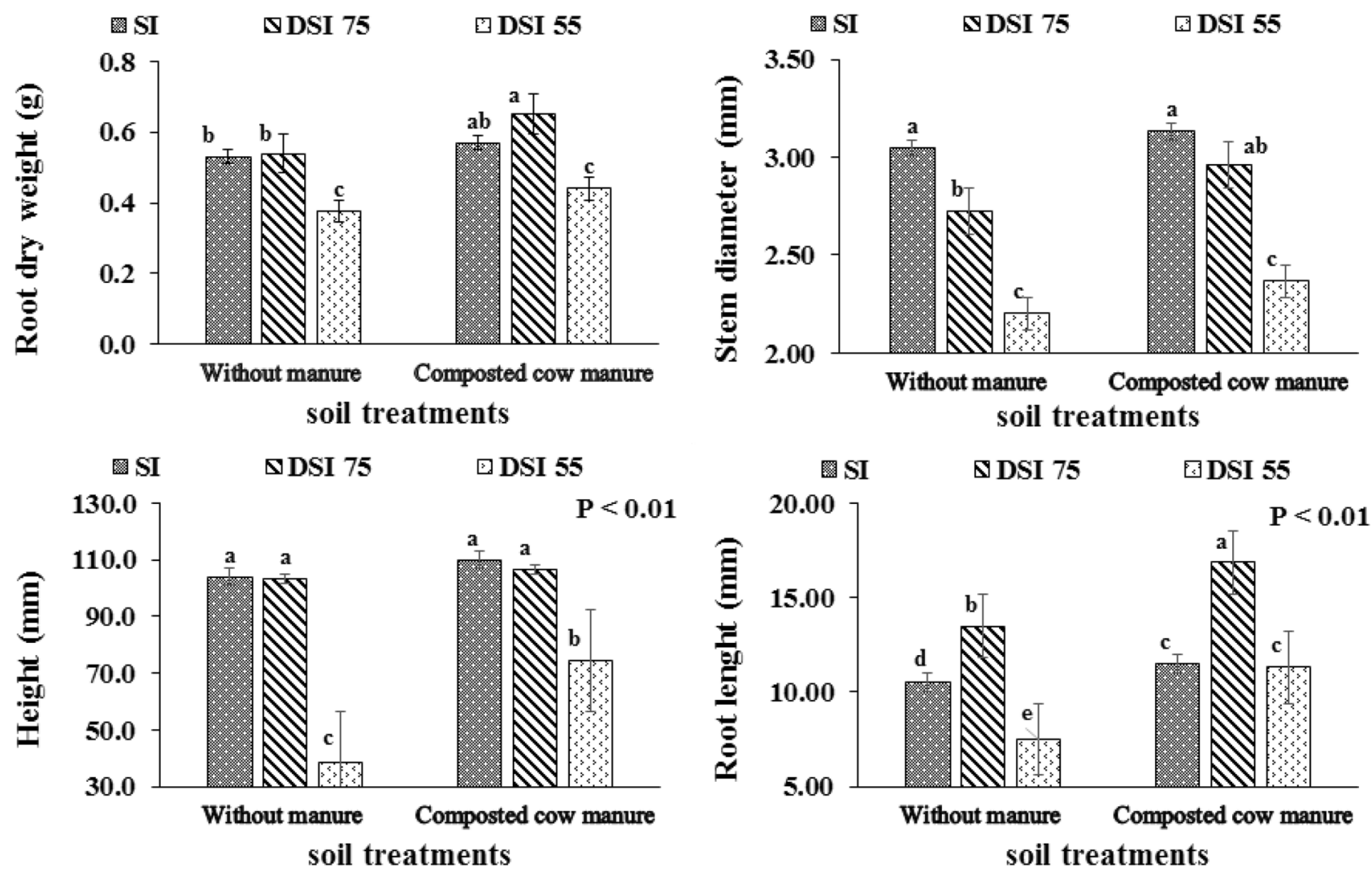

SI: Full irrigation with saline water, DSI75: $75 \%$ of SI and DSI55: $55 \%$ of SI

Fig. 1 Effects of irrigation and soil treatments on physiological traits of $S$. persica. *Values are means \pm s.e. Means with the same letter are not significantly different (Duncan test, level of significance shown in each graph) 
hand, reported crop yield and characteristics under mild water stress show similar result compared to full irrigation (Chuanjie et al. 2015).

The highest values for the root length and root weight were achieved in $\mathrm{DSI}_{75}-\mathrm{CM}$, and the lowest were observed in $\mathrm{DSI}_{55}$-WA. Root length in this experiment varied between 7.5 and $16.9 \mathrm{~mm} \mathrm{plant}^{-1}$, and root dry weight varied between 0.4 and $0.7 \mathrm{~g} \mathrm{plant}^{-1}$. Plants that face mild water stress try to absorb more water to continue their growth, and as a result, the length and weight of root increase. Enhancement of root properties under water stress is reported by other researchers for cotton (Oweis
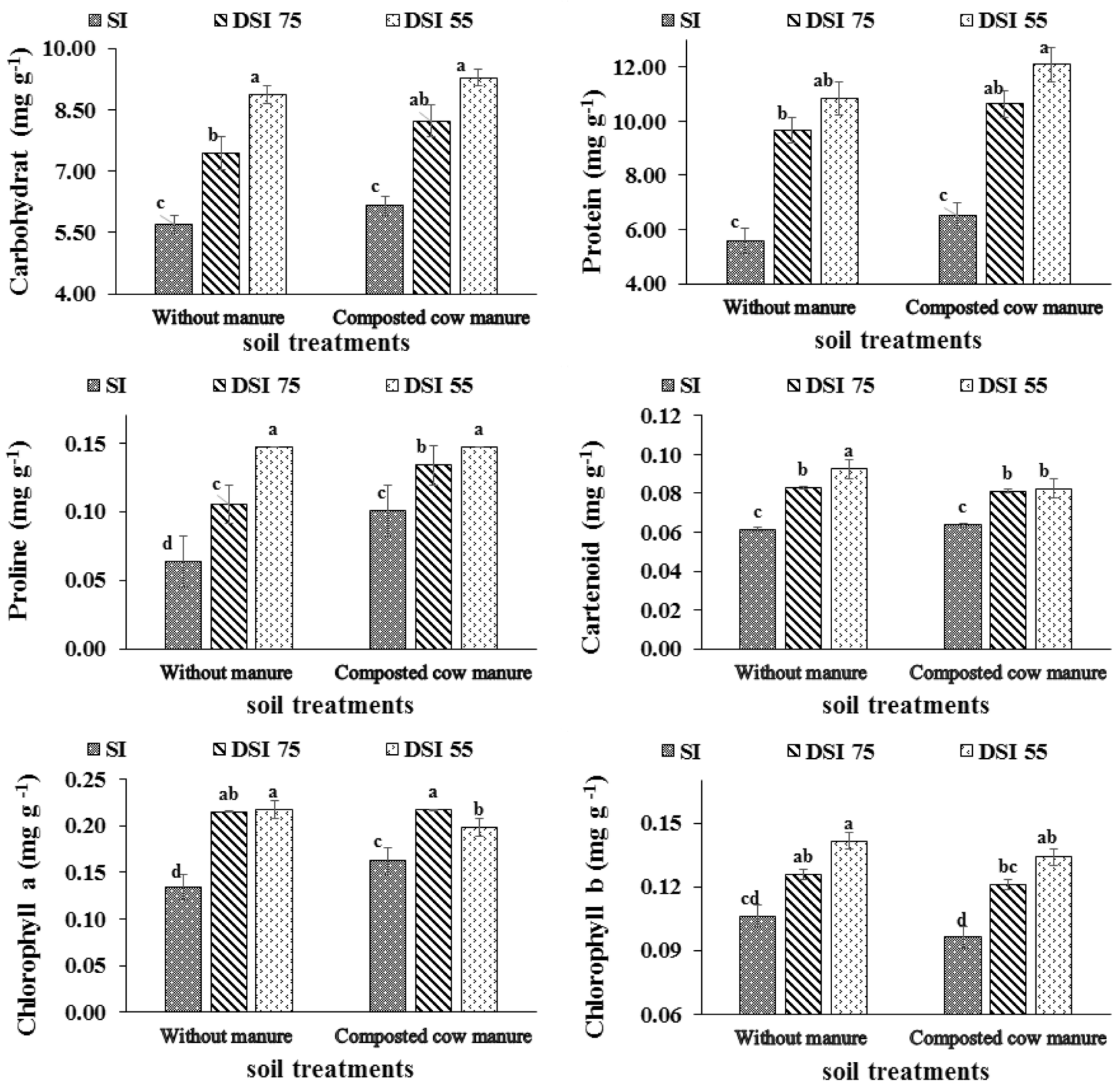

SI: Full irrigation with saline water, DSI75: $75 \%$ of SI and DSI55: 55\% of SI

Fig. 3 Effects of irrigation and soil treatments on bio-chemical traits of $S$. persica. *Values are means \pm s.e. Means with the same letter are not significantly different (Duncan test, level of significance shown in each graph) 
et al. 2011; Rao et al. 2016), ornamental plants (Chyliński et al. 2007; Sánchez-Blanco et al. 2019; Shober et al. 2009), maize (Gheysari et al. 2017) and wheat (Xue et al. 2003).

\section{Chemical traits of Salicornia}

Chemical responses of $S$. persica under treatments are presented in Fig. 3. In this study, carbohydrates $\left(5.7-9.28 \mathrm{mg} \mathrm{g}^{-1}\right)$, protein $\left(5.56-12.09 \mathrm{mg} \mathrm{g}^{-1}\right)$, proline $\left(0.06-0.15 \mathrm{mg} \mathrm{g}^{-1}\right)$, carotenoid $\left(0.06-0.08 \mathrm{mg} \mathrm{g}^{-1}\right)$, chlorophyll $a\left(0.13-0.22 \mathrm{mg} \mathrm{g}^{-1}\right)$ and chlorophyll $b$ (0.10-0.14 $\left.\mathrm{mg} \mathrm{g}^{-1}\right)$ were investigated. Deficit irrigation had significant effects on chemical parameters. The highest and lowest values for them were obtained in $\mathrm{DSI}_{55}$ and SI, respectively. This is supported by many studies that water stress may strongly increase these parameters (Ebtedaie and Shekafandeh 2016; Sun et al. 2016). Chemical parameters play some important roles in osmoprotecting, repairing damage of tissue and supporting growth (Llanes et al. 2018). Additionally, drought-tolerant cultivars have higher levels of metabolite than drought-sensitive cultivars (Nyarukowa et al. 2016). On the other hand, some researchers found that with increasing salinity levels, proline content rise, while chlorophyll and carotenoid reduce for Salicornia prostrata and Suaeda prostrata (Akcin and Yalcin 2016) and for peppermint (Xu et al. 2016).

$\mathrm{Na}^{+}$accumulation in plants under WA was around 9\% higher than CM. In other words, under WA conditions plants accumulated higher amounts of $\mathrm{Na}^{+}$(Fig. 4). Furthermore, the highest value of $\mathrm{Na}^{+}$was obtained in $\mathrm{DSI}_{75}$ with 202 $\left(\right.$ meq $1^{-1}$ ) for WA and $179\left(\right.$ meq $1^{-1}$ ) for CM. Accumulation of $\mathrm{K}^{+}$in plant shows contrasting results compared with
Table 3 WUE, used and saved saline water during the experiment

\begin{tabular}{lllll}
\hline Treatments & $\begin{array}{l}\text { Plant water } \\
\text { use }(1 \\
\text { plant }\end{array}$ & $\begin{array}{l}\text { Plant dry } \\
\text { biomass } \\
\left.\text { plant }^{-1}\right)\end{array}$ & WUE $\left(\mathrm{g} \mathrm{l}^{-1}\right)$ & $\begin{array}{l}\text { Saved water } \\
\%\end{array}$ \\
\hline SI-WA & 0.22 & 0.38 & 1.73 & - \\
SI-CM & 0.22 & 0.51 & 2.32 & - \\
DSI $_{75}$-WA & 0.18 & 0.35 & 1.94 & 17.4 \\
DSI $_{75}$-CM & 0.18 & 0.47 & 2.61 & 17.4 \\
DSI $_{55}$-WA & 0.15 & 0.2 & 1.33 & 31.3 \\
DSI $_{55}$-CM & 0.15 & 0.27 & 1.80 & 31.3 \\
\hline
\end{tabular}

$\mathrm{Na}^{+}$. The values of $\mathrm{K}^{+}$accumulation for $\mathrm{CM}$ treatments were $160 \%$ higher than WA in different irrigation treatments. Additionally, deficit irrigation shows a significant effect $(p<0.01)$ on $\mathrm{K}^{+}$accumulation, and the highest value (25.8 meq $\mathrm{l}^{-1}$ ) was observed in $\mathrm{DSI}_{55}$-CM. Other studies reported that ions accumulation increases under water and salinity stresses (Álvarez and Sánchez-Blanco 2015). Enhancement of salinity levels led to an increase and decrease in sodium and potassium concentrations, respectively (Atzori et al. 2017). The use of vermicompost can reduce the accumulation of $\mathrm{Na}^{+}$and increase the $\mathrm{K}^{+} / \mathrm{Na}^{+}$ ratio in peppermint (Xu et al. 2016).

\section{Water-use efficiency (WUE)}

An amount of 0.22-0.15 1 plant ${ }^{-1}$ of saline water was used during the experiment. The highest and lowest values of used water belong to SI and $\mathrm{DSI}_{55}$, respectively (Table 3). Consumption of saline water under $\mathrm{DSI}_{75}$ and $\mathrm{DSI}_{55}$ was $17.4 \%$ and 31.3\% lower than SI, respectively. As our results show,
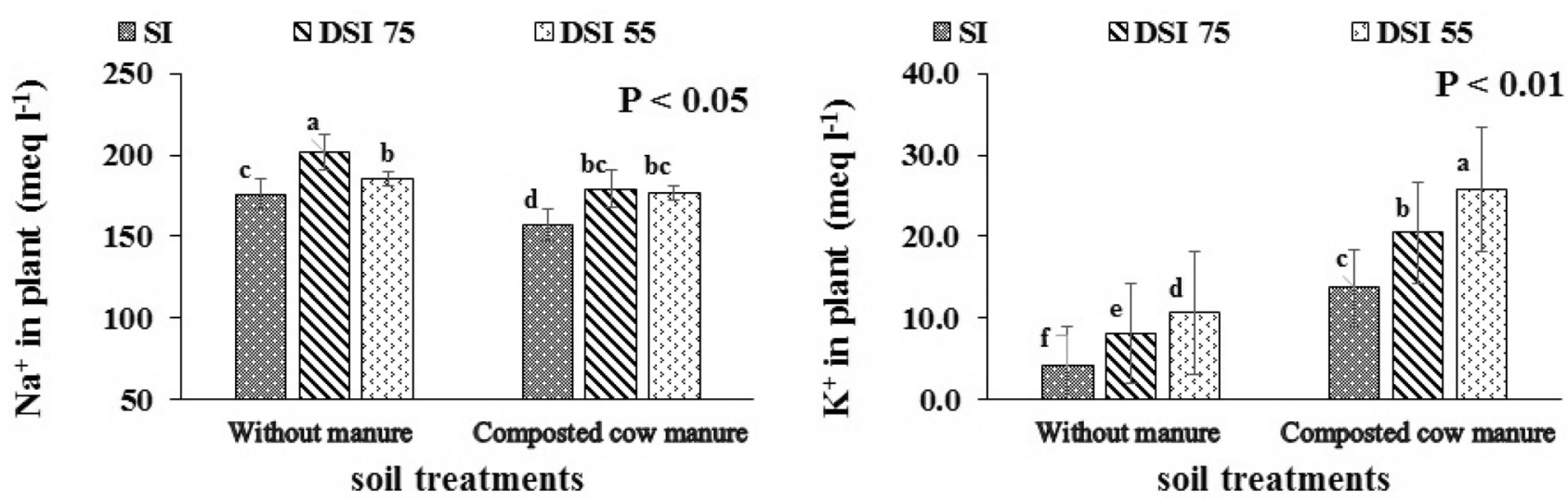

SI: Full irrigation with saline water, DSI75: $75 \%$ of SI and DSI55: $55 \%$ of SI

Fig. 4 Effects of irrigation and soil treatments on ion accumulation in plant. *Values are means \pm s.e. Means with the same letter are not significantly different (Duncan test, level of significance shown in each graph) 
plant dry biomass varied between 0.51 and $0.20 \mathrm{~g} \mathrm{plant}^{-1}$, and application of CM caused an increase of 33\% in dry biomass in different irrigation treatments, approximately. In other words, CM reduced the negative effect of deficit irrigation.

The WUE values varied from $1.33 \mathrm{~g} \mathrm{l}^{-1}\left(\mathrm{DSI}_{55^{-}}\right.$WA) to $2.61 \mathrm{~g} \mathrm{l}^{-1}\left(\mathrm{DSI}_{75}-\mathrm{CM}\right)$. Table 3 shows that application of CM could improve WUE around 34\% compared to respective treatments under WA. In addition, the WUE value of $\mathrm{DSI}_{75}$-WA was $12.1 \%$ higher than SI-WA, and $\mathrm{DSI}_{75}-\mathrm{CM}$ was $12.5 \%$ higher than SI-CM. The comparison of WUE values between $\mathrm{DSI}_{75^{-}} \mathrm{CM}$ with $2.61 \mathrm{~g}^{-1}$ and SI-WA with $1.73 \mathrm{~g} \mathrm{l}^{-1}$ shows a $50.9 \%$ enhancement for $\mathrm{DSI}_{75}-\mathrm{CM}$. This indicates that the combination of $\mathrm{DSI}_{75}$ and $\mathrm{CM}$ not only reduces the water used but also could increase the WUE compared to control conditions. Increasing WUE under deficit irrigation has been reported for different crops (Chuanjie et al. 2015; Yuan et al. 2019). Moreover, in both glycophytes and halophytes, salinity conditions are often correlated with an increased WUE. In glycophytes, the increased WUE in salinity conditions has been related to a reduced stomatal conductance (Atzori et al. 2016) and to decreased water consumption (Atzori et al. 2019), whereas in halophytes, i.e., A. tricolor and A. cruentus, the increased WUE was due to reduction in stomatal density (Srinivas et al. 2018).

\section{Soil salinity}

The electrical conductivity, $\mathrm{pH}, \mathrm{Na}^{+}$and $\mathrm{K}^{+}$in the soil after the experiment are presented in Fig. 5. Our results indicate that the soil salinity and ion accumulation significantly decreased under all treatments compared with the beginning of the experiment, with values for $\mathrm{EC}$ and $\mathrm{Na}^{+}$ of $8.3 \mathrm{dS} \mathrm{m}^{-1}$ and $62.3 \mathrm{meq}^{-1}$, respectively. However, full irrigation with saline water decreased EC more than deficit irrigations. This may occur due to the following reasons: The greater volume of drainage water under full irrigation can enhance both the leaching process of desalination and better growth of plant under full irrigation compared to $\mathrm{DSI}_{55}$. The soil EC values at the end of experiment for $\mathrm{DSI}_{75}$ and
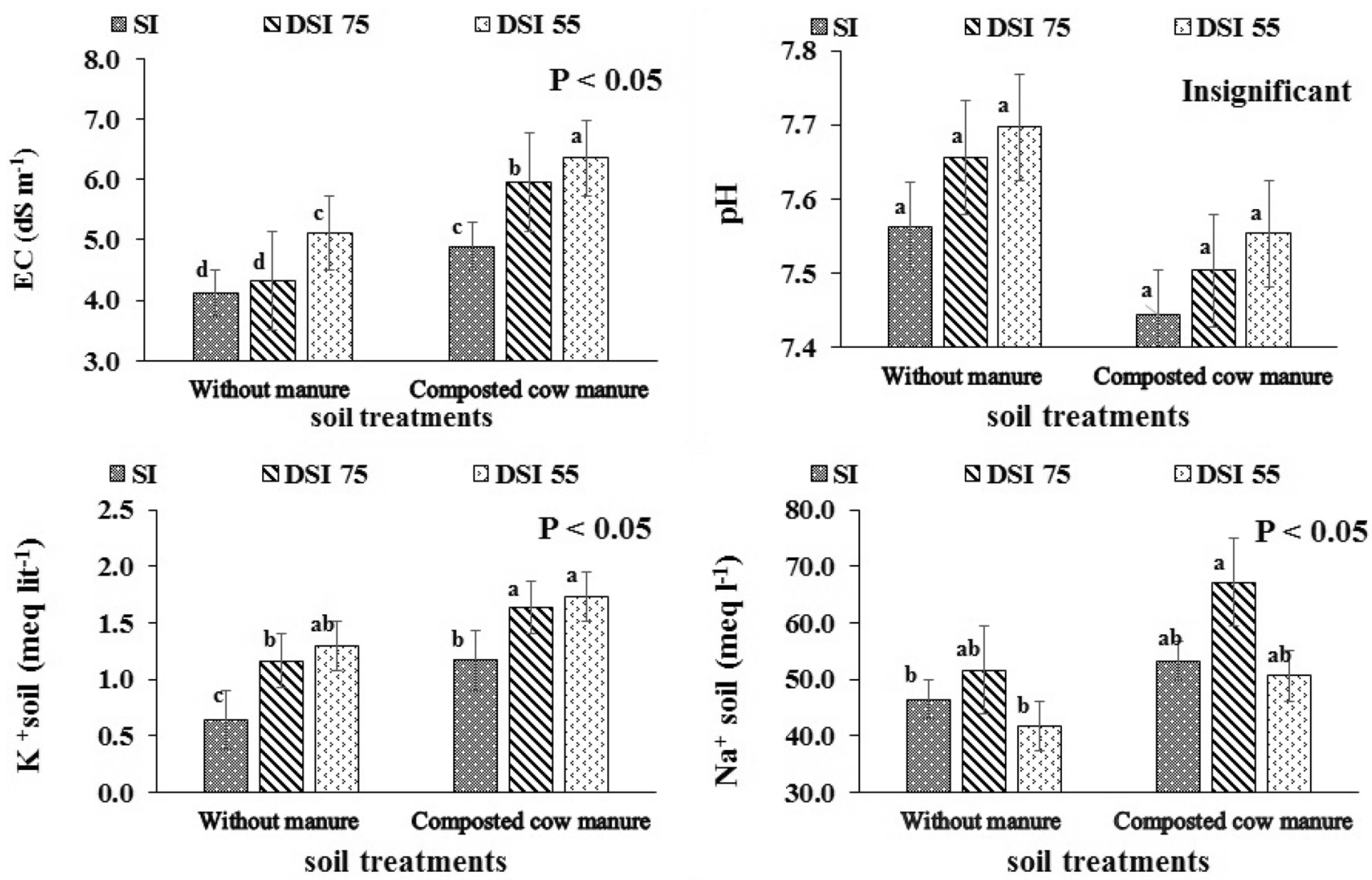

SI: Full irrigation with saline water, DSI75: $75 \%$ of SI and DSI55: 55\% of SI

Fig. 5 Effects of irrigation and soil treatments on soil parameters at the end of experiment. *Values are means \pm s.e. Means with the same letter are not significantly different (Duncan test, level of significance shown in each graph) 
$\mathrm{DSI}_{55}$ were $13.7 \%$ and $27.2 \%$ higher compared to SI, respectively. Similar results were observed for $\mathrm{pH}$ and $\mathrm{K}^{+}$. The soil $\mathrm{pH}$ and the accumulation of $\mathrm{K}^{+}$for $\mathrm{DSI}_{75}$ and $\mathrm{DSI}_{55}$ were $1.02 \%$ and $1.6 \%$ and $54.2 \%$ and $67 \%$, respectively, higher than SI. However, the accumulation of $\mathrm{Na}^{+}$showed some different results: The highest value for $\mathrm{Na}^{+}$was observed in $\mathrm{DSI}_{75^{-}} \mathrm{CM}\left(67.1 \mathrm{meq}^{-1}\right)$, and the lowest value was observed in $\mathrm{DSI}_{55}$-WA (41.8 meq $\mathrm{l}^{-1}$ ). These results may be related to interaction effects between saline water and $\mathrm{Na}^{+}$absorption under CM treatment. CM can improve cation exchange capacity of soil (Jalali and Ranjbar 2009; Walker and Bernal 2008). Additionally, it has a high value of $\mathrm{Ca}^{2+}$ and $\mathrm{Mg}^{2+}$. Therefore, soil particles might have absorbed those ions and released $\mathrm{Na}^{+}$. It seems SI could transfer the $\mathrm{Na}^{+}$through drainage water, while in the $\mathrm{DSI}_{75}$ or $\mathrm{DSI}_{55}$ we do not have any drainage water. Therefore, $\mathrm{Na}^{+}$just was extracted from soil by plant forces. The volume of saline water in $\mathrm{DSI}_{55}$ was lower than other treatments. As a result, accumulation of $\mathrm{Na}^{+}$decreased in $\mathrm{DSI}_{55}$ compared to SI or DSI $\mathrm{DI}_{75}$. Although the application of $\mathrm{CM}$ could enhance the plant growth compared to WA, on average, the use of CM increased EC, $\mathrm{Na}^{+}$ and $\mathrm{K}^{+}$by $26.9 \%, 46.2 \%$ and $22.2 \%$, respectively, compared to WA. On the other hand, soil $\mathrm{pH}$ decreased $1.8 \%$ under the use of CM compared to WA. However, this reduction was not significant.

The concentration of $\mathrm{Na}^{+}$and $\mathrm{Cl}^{-}$and the value of EC were significantly decreased under phyto-desalination with other kinds of halophytes including Artemisia argyi L., Limonium bicolor K., Melilotus suaveolens L. and Salsola collina P (Sakai et al. 2012). Tecticornia indica and Suaeda fruticosa had suitable results for soil desalination (Rabhi et al. 2009) as well as T. indica and S. fruticose that electrical conductivity and soluble sodium decreased significantly under their cultivation (Rabhi et al. 2010). Additionally, for other kinds of halophytes such as Atriplex nummularia, similar results were reported (de Melo et al. 2018). Interaction effects between Salicornia europaea and three different rates of ameliorant to improve saline-alkaline soil showed that the beneficial effects of cow dung were higher than others, and it could reduce the $\mathrm{Na}^{+}$stress (Li-ping et al. 2015). In addition, composted cattle manure was reported as one of the best amendments for increasing agronomic and environmental behavior (Horta et al. 2018).

\section{Conclusion}

One of the points of desalinization methods is to achieve suitable results in a short time, as well as considering environmental conditions. Therefore, in this study, a short-time experiment was designed to investigate the effects of the combination of saline irrigation at three different levels and soil conditions (both excluding and including composted cow manure) on S. persica growth and soil desalinization. The overall results illustrate that the combination of SI and $\mathrm{CM}$ could produce the highest values for dry weight, height and stem diameter. On the other hand, the combination of $\mathrm{DSI}_{75}$ and CM increased WUE, root length and weight compared to SI-CM. The application of deficit irrigation led to the increasing of chemical traits in S. persica. The results show that accumulation of $\mathrm{Na}^{+}$in plants under WA was $9 \%$ higher than $\mathrm{CM}$. The $\mathrm{DSI}_{75}$ treatment could encourage the plant to absorb more $\mathrm{Na}^{+}$with $14.5 \%$ and $5.1 \%$ compared to SI and $\mathrm{DSI}_{55}$, respectively. The accumulation of $\mathrm{K}^{+}$in plants under CM was $160 \%$ higher than WA. The application of $\mathrm{DSI}_{55}$ and $\mathrm{DSI}_{75}$ increased the $\mathrm{K}^{+}$concentration with $104 \%$ and $60.2 \%$ compared to SI. Soil electrical conductivity significantly decreased from $8.3 \mathrm{dS} \mathrm{m}^{-1}$ (i.e., before the experiment) to $5.1 \mathrm{dS} \mathrm{m}^{-1}$ in average of all treatments, with the highest and lowest reductions associated with SI-WA $\left(4.1 \mathrm{dS} \mathrm{m}^{-1}\right)$ and $\mathrm{DSI}_{55^{-}} \mathrm{CM}\left(6.4 \mathrm{dS} \mathrm{m}^{-1}\right)$, respectively. Although the application of CM could increase crop growth, the EC values were higher under CM treatments compared to WAs. The positive effects of our suggested methodology should be investigated in long-term experiments under field conditions.

Acknowledgements We would like to show our gratitude to the Sistan Agricultural and Natural Resources Research and Education Center.

\section{References}

Afshar RK, Chaichi M, Assareh M, Hashemi M, Liaghat A (2014) Interactive effect of deficit irrigation and soil organic amendments on seed yield and flavonolignan production of milk thistle (Silybum marianum L. Gaertn). Ind Crops Prod 58:166-172

Akcin A, Yalcin E (2016) Effect of salinity stress on chlorophyll, carotenoid content, and proline in Salicornia prostrata Pall. and Suaedaprostrata Pall. subsp. prostrata (Amaranthaceae). Braz J Bot 39:101-106

Akinshina N, Azizov A, Karasyova T, Klose E (2016) On the issue of halophytes as energy plants in saline environment. Biomass Bioenergy 91:306-311

Al-Ghobari HM, Dewidar AZ (2018) Integrating deficit irrigation into surface and subsurface drip irrigation as a strategy to save water in arid regions. Agric Water Manag 209:55-61

Allen RG, Pereira LS, Raes D, Smith M (1998) Crop evapotranspiration-guidelines for computing crop water requirements-FAO Irrigation and drainage paper 56. FAO Rome 300:D05109

Álvarez S, Sánchez-Blanco MJ (2015) Comparison of individual and combined effects of salinity and deficit irrigation on physiological, nutritional and ornamental aspects of tolerance in Callistemon laevis plants. J Plant Physiol 185:65-74

Aly AA, Al-Barakah FN, El-Mahrouky MA (2018) Salinity stress promote drought tolerance of Chenopodium quinoa Willd. Commun Soil Sci Plant Anal 49:1331-1343

Ashraf M, Foolad M (2007) Roles of glycine betaine and proline in improving plant abiotic stress resistance. Environ Exp Bot 59:206-216 
Ashraf M, Orooj A (2006) Salt stress effects on growth, ion accumulation and seed oil concentration in an arid zone traditional medicinal plant ajwain (Trachyspermum ammi [L.] Sprague). J Arid Environ 64:209-220

Atzori G et al (2016) Potential and constraints of different seawater and freshwater blends as growing media for three vegetable crops. Agric Water Manag 176:255-262

Atzori G, de Vos AC, van Rijsselberghe M, Vignolini P, Rozema J, Mancuso S, van Bodegom PM (2017) Effects of increased seawater salinity irrigation on growth and quality of the edible halophyte Mesembryanthemum crystallinum L. under field conditions. Agric Water Manag 187:37-46

Atzori G, Nissim WG, Caparrotta S, Santantoni F, Masi E (2019) Seawater and water footprint in different cropping systems: a chicory (Cichorium intybus L.) case study. Agric Water Manag 211:172-177

Ayala F, O'Leary JW (1995) Growth and physiology of Salicornia bigelovii Torr. at suboptimal salinity. Int J Plant Sci 156:197-205

Ayars J, Christen E, Soppe R, Meyer W (2006) The resource potential of in-situ shallow ground water use in irrigated agriculture: a review. Irrig Sci 24:147-160

Azhar N, Hussain B, Ashraf MY, Abbasi KY (2011) Water stress mediated changes in growth, physiology and secondary metabolites of desi ajwain (Trachyspermum ammi L.). Pak J Bot 43:15-19

Behera S, Panda R (2009) Integrated management of irrigation water and fertilizers for wheat crop using field experiments and simulation modeling. Agric Water Manag 96:1532-1540

Bekmirzaev G, Beltrao J, Ouddane B (2019) Effect of irrigation water regimes on yield of Tetragonia tetragonioides. Agriculture 9:22

Béné C, Barange M, Subasinghe R, Pinstrup-Andersen P, Merino G, Hemre G-I, Williams M (2015) Feeding 9 billion by 2050-putting fish back on the menu. Food Secur 7:261-274

Bistgani ZE, Siadat SA, Bakhshandeh A, Pirbalouti AG, Hashemi M, Maggi F, Morshedloo MR (2018) Application of combined fertilizers improves biomass, essential oil yield, aroma profile, and antioxidant properties of Thymus daenensis Celak. Ind Crops Prod 121:434-440

Böer B, Khan MA, Koyro H-W, Marcum KB (2016) Prospects of environmentally friendly farms for food security in hot and dry coastal areas based on seawater irrigation and wasteproducts-an inspirational proposal. In: Khan MA, Boër B, Ôzturk M, ClüsenerGodt M, Gul B, Breckle SW (eds) Sabkha ecosystems. Springer, Berlin, pp 1-10

Bohnert HJ, Nelson DE, Jensen RG (1995) Adaptations to environmental stresses. Plant Cell 7:1099

Brar A, Buttar G, Sharma R (2018) Water and energy productivity of rice as influenced by duration of cultivars, dates of transplanting and irrigation regime in north-western India. Paddy Water Environ 16:655-663

Caraballo MA, Macías F, Nieto JM, Ayora C (2016) Long term fluctuations of groundwater mine pollution in a sulfide mining district with dry Mediterranean climate: implications for water resources management and remediation. Sci Total Environ 539:427-435

Carlton A, Cameron K, Edwards G, Di HJ, Clough T (2016) The effect of optimum vs. deficit irrigation on plant nitrogen uptake and nitrate leaching loss from soil. Integr Nutr Water Manag Sustain Farm 29:1-4

Cheeseman JM (2015) The evolution of halophytes, glycophytes and crops, and its implications for food security under saline conditions. New Phytol 206:557-570

Chuanjie Y, Yi L, Lin S, Na W (2015) Effect of deficit irrigation on the growth, water use characteristics and yield of cotton in arid Northwest China. Pedosphere 25:910-924
Chyliński WK, Łukaszewska AJ, Kutnik K (2007) Drought response of two bedding plants. Acta Physiol Plant 29:399

Csiszar A et al (2007) Downregulation of bone morphogenetic protein 4 expression in coronary arterial endothelial cells: role of shear stress and the cAMP/protein kinase A pathway. Arterioscler Thromb Vasc Biol 27:776-782

Dağdelen N, Başal H, Yılmaz E, Gürbüz T, Akcay S (2009) Different drip irrigation regimes affect cotton yield, water use efficiency and fiber quality in western Turkey. Agric Water Manag 96:111-120

de Melo HF, de Souza ER, de Almeida BG, Mulas M (2018) Water potential in soil and Atriplex nummularia (phytoremediator halophyte) under drought and salt stresses. Int J Phytoremediat 20:249-255

Devi NC, Mazumder PB, Bhattacharjee A (2018) Statistical optimization of polyhydroxybutyrate production by Bacillus pumilus $\mathrm{H} 9$ using cow dung as a cheap carbon source by response surface methodology. J Polym Environ 26:3159-3167

Dorji K, Behboudian M, Zegbe-Dominguez J (2005) Water relations, growth, yield, and fruit quality of hot pepper under deficit irrigation and partial rootzone drying. Sci Hortic 104:137-149

Ebtedaie M, Shekafandeh A (2016) Antioxidant and carbohydrate changes of two pomegranate cultivars under deficit irrigation stress. Span J Agric Res 14:19

Falasca SL, Ulberich A, Acevedo A (2014) Identification of Argentinian saline drylands suitable for growing Salicornia bigelovii for bioenergy. Int J Hydrog Energy 39:8682-8689

Flowers TJ, Colmer TD (2008) Salinity tolerance in halophytes. New Phytol 179:945-963

Galindo A et al (2018) Deficit irrigation and emerging fruit crops as a strategy to save water in Mediterranean semiarid agrosystems. Agric Water Manag 202:311-324

Gheysari M et al (2017) Comparison of deficit irrigation management strategies on root, plant growth and biomass productivity of silage maize. Agric Water Manag 182:126-138

Glenn EP, Brown JJ, O'Leary JW (1998) Irrigating crops with seawater. Sci Am 279:76-81

Glenn EP, Mckeon C, Gerhart V, Nagler PL, Jordan F, Artiola J (2009) Deficit irrigation of a landscape halophyte for reuse of saline waste water in a desert city. Landsc Urban Plan 89:57-64

Guilpart N, Roux S, Gary C, Metay A (2017) The trade-off between grape yield and grapevine susceptibility to powdery mildew and grey mould depends on inter-annual variations in water stress. Agric For Meteorol 234:203-211

Gunning D (2016) Cultivating Salicornia europaea (marsh samphire). Daithi O’Murchu Marine Research Station \& University College Cork, Dublin, pp 1-50

Horta C, Roboredo M, Carneiro JP, Duarte AC, Torrent J, Sharpley A (2018) Organic amendments as a source of phosphorus: agronomic and environmental impact of different animal manures applied to an acid soil. Arch Agron Soil Sci 64:257-271

Jalali M, Ranjbar F (2009) Effects of sodic water on soil sodicity and nutrient leaching in poultry and sheep manure amended soils. Geoderma 153:194-204

Jonubi R, Rezaverdinejad V, Salemi H (2018) Enhancing field scale water productivity for several rice cultivars under limited water supply. Paddy Water Environ 16:125-141

Kalantari E, Hassanli A, Ghanbarian GA, Ghaemi AA, Mousavi SR (2018) Local desalination treatment plant wastewater reuse and evaluation potential absorption of salts by the halophyte plants. Eurasian J Soil Sci 7:43-50

Li-ping L, Xiao-hua L, Hong-bo S, Zhao-Pu L, Ya T, Quan-suo Z, Junqin Z (2015) Ameliorants improve saline-alkaline soils on a large scale in northern Jiangsu Province, China. Ecol Eng 81:328-334

Liu X, Xia Y, Wang F, Sun M, Jin Z, Wang G (2005) Analysis of fatty acid composition of Salicornia europaea L. seed oil. Food Sci $2: 42$ 
Llanes A, Andrade A, Alemano S, Luna V (2018) Metabolomic approach to understand plant adaptations to water and salt stress. In: Ahmad P, Ahanger MA, Singh VP, Tripathi DK, Alam P, Alyemeni MN (eds) Plant metabolites and regulation under environmental stress. Elsevier, Amsterdam, pp 133-144

Manousaki E, Galanaki K, Papadimitriou L, Kalogerakis N (2014) Metal phytoremediation by the halophyte Limoniastrum monopetalum (L.) Boiss: two contrasting ecotypes. Int J Phytoremediat 16:755-769

Min W, Guo H, Zhou G, Zhang W, Ma L, Ye J, Hou Z (2014) Root distribution and growth of cotton as affected by drip irrigation with saline water. Field Crops Res 169:1-10

Miyamoto S, Chacon A (2006) Soil salinity of urban turf areas irrigated with saline water: II. Soil factors. Landsc Urban Plan 77:28-38

Moussavi-Nik SM, Salari M, Mobasser HR, Keshavarzi M (2011) The effect of different irrigation intervals and mineral nutrition on seed yield of Ajowan (Trachyspermum ammi). Ann Biol Res 2:692-698

Muschal M (2006) Assessment of risk to aquatic biota from elevated salinity - a case study from the Hunter River, Australia. J Environ Manag 79:266-278

Nakawuka P, Peters TR, Kenny S, Walsh D (2017) Effect of deficit irrigation on yield quantity and quality, water productivity and economic returns of four cultivars of hops in the Yakima Valley, Washington State. Ind Crops Prod 98:82-92

Nazli RI, Inal I, Kusvuran A, Demirbas A, Tansi V (2016) Effects of different organic materials on forage yield and nutrient uptake of silage maize (Zea mays L.). J Plant Nutr 39:912-921

Nikalje GC, Srivastava AK, Pandey GK, Suprasanna P (2018) Halophytes in biosaline agriculture: mechanism, utilization, and value addition. Land Degrad Dev 29:1081-1095

Nouri H et al (2017) Application of green remediation on soil salinity treatment: a review on halophytoremediation. Process Saf Environ Prot 107:94-107

Nyarukowa C, Koech R, Loots T, Apostolides Z (2016) SWAPDT: a method for short-time withering assessment of probability for drought tolerance in Camellia sinensis validated by targeted metabolomics. J Plant Physiol 198:39-48

Ohori T, Fujiyama H (2011) Water deficit and abscisic acid production of Salicornia bigelovii under salinity stress. Soil Sci Plant Nutr 57:566-572

Ostad-Ali-Askari K, Shayannejad M, Ghorbanizadeh-Kharazi H (2017) Artificial neural network for modeling nitrate pollution of groundwater in marginal area of Zayandeh-rood River Isfahan, Iran. KSCE J Civ Eng 21:134-140

Oweis T, Farahani H, Hachum A (2011) Evapotranspiration and water use of full and deficit irrigated cotton in the Mediterranean environment in northern Syria. Agric Water Manag 98:1239-1248

Pamarthy J, Bhat V, Sukumaran M (2016) A comparative study on Casein and Albumin contents in cow and commercial milk samples. IOSR J Dent Med Sci 3(4):2

Pandey V, Patra D (2015) Crop productivity, aroma profile and antioxidant activity in Pelargonium graveolens L'Hér under integrated supply of various organic and chemical fertilizers. Ind Crops Prod 67:257-263

Pereira LS, Oweis T, Zairi A (2002) Irrigation management under water scarcity. Agric Water Manag 57:175-206

Price LL (2007) From pedestrian fare to gourmet trend: the case of Salicornia europaea L., a traditional gathered wild seashore vegetable. In: Moerbeek HH, Niehof A (eds) Changing families and their lifestyles, vol 5. Wageningen Academic Publishers, pp 201-211

Qureshi AS (2017) Sustainable use of marginal lands to improve food security in the United Arab Emirates. J Exp Biol Agric Sci 5:S41-S49
Rabhi M et al (2009) Evaluation of the capacity of three halophytes to desalinize their rhizosphere as grown on saline soils under nonleaching conditions. Afr J Ecol 47:463-468

Rabhi M, Karray-Bouraoui N, Medini R, Attia H, Abdelly C, Smaoui A (2010) Seasonal variations in phytodesalination capacity of two perennial halophytes in their natural biotope. J Biol Res 14:181

Rao SS, Tanwar SPS, Regar PL (2016) Effect of deficit irrigation, phosphorous inoculation and cycocel spray on root growth, seed cotton yield and water productivity of drip irrigated cotton in arid environment. Agric Water Manag 169:14-25

Reddy MS et al (2010) Bromide tolerance in plants: a case study on halophytes of Indian coast SRX. Ecology 2010:1-6

Saboora A, Parsiavash L, Moosavi-Nejad Z (2012) Purification and kinetic properties of guaiacol peroxidase in turnip (Brassica napus var okapi) root during different growth stages. Prog Biol Sci 2:76-86

Sakai Y, Ma Y, Xu C, Wu H, Zhu W, Yang J (2012) Phytodesalination of a salt-affected soil with four halophytes in China. J Arid Land Stud 22:17-20

Sánchez-Blanco M, Ortuño M, Bañon S, Álvarez S (2019) Deficit irrigation as a strategy to control growth in ornamental plants and enhance their ability to adapt to drought conditions. J Hortic Sci Biotechnol 94:137-150

Sardinha M, Müller T, Schmeisky H, Joergensen RG (2003) Microbial performance in soils along a salinity gradient under acidic conditions. Appl Soil Ecol 23:237-244

Shober AL et al (2009) Posttransplant irrigation frequency affects growth of container-grown sweet viburnum in three hardiness zones. HortScience 44:1683-1687

Sikuku P, Netondo G, Onyango J, Musyimi D (2010) Chlorophyll fluorescence, protein and chlorophyll content of three nerica rainfed rice varieties under varying irrigation regimes. ARPN J Agric Biol Sci 5:19-25

Smedema LK, Shiati K (2002) Irrigation and salinity: a perspective review of the salinity hazards of irrigation development in the arid zone. Irrig Drain Syst 16:161-174

Srinivas A, Rajasheker G, Jawahar G, Devineni PL, Parveda M, Kumar SA, Kishor PBK (2018) Deploying mechanisms adapted by halophytes to improve salinity tolerance in crop plants: focus on anatomical features, stomatal attributes, and water use efficiency. In: Salinity responses and tolerance in plants, vol 1. Springer, Berlin, pp 41-64

Sun C, Li M, Gao X, Liu L, Wu X, Zhou J (2016) Metabolic response of maize plants to multi-factorial abiotic stresses. Plant Biol $18: 120-129$

Talebnejad R, Sepaskhah A (2015) Effect of deficit irrigation and different saline groundwater depths on yield and water productivity of quinoa. Agric Water Manag 159:225-238

Teh SY, Koh HL (2016) Climate change and soil salinization: impact on agriculture, water and food security. Int J Agric For Plant 2:1-9

Walker DJ, Bernal MP (2008) The effects of olive mill waste compost and poultry manure on the availability and plant uptake of nutrients in a highly saline soil. Biores Technol 99:396-403

Wang Y, Janz B, Engedal T, de Neergaard A (2017) Effect of irrigation regimes and nitrogen rates on water use efficiency and nitrogen uptake in maize. Agric Water Manag 179:271-276

Xu L, Yan D, Ren X, Wei Y, Zhou J, Zhao H, Liang M (2016) Vermicompost improves the physiological and biochemical responses of blessed thistle (Silybum marianum Gaertn.) and peppermint (Mentha haplocalyx Briq) to salinity stress. Ind Crops Prod 94:574-585

Xue Q, Zhu Z, Musick J, Stewart B, Dusek D (2003) Root growth and water uptake in winter wheat under deficit irrigation. Plant Soil 257:151-161

Yuan C, Feng S, Huo Z, Ji Q (2019) Effects of deficit irrigation with saline water on soil water-salt distribution and water use efficiency of maize for seed production in arid Northwest China. Agric Water Manag 212:424-432 
Zandvakili OR, Ebrahimi E, Hashemi M, Barker AV, Akbari P (2017) The potential of green manure mixtures to provide nutrients to a subsequent lettuce crop. Commun Soil Sci Plant Anal 48:2246-2255
Zhang M, Hettiarachchy NS, Horax R, Chen P, Over KF (2009) Effect of maturity stages and drying methods on the retention of selected nutrients and phytochemicals in bitter melon (Momordica charantia) leaf. J Food Sci 74:C441-C448 